\title{
Analysis of Serological Variability and Hierarchical Distribution of Rice yellow mottle Sobemovirus Isolates in Northern Nigeria
}

\author{
Alkali $^{1, *}$ G., Alegbejo ${ }^{2}$ M. D., Kashina ${ }^{2}$ B. D., Banwo ${ }^{2}$ O. O. \\ ${ }^{1}$ Department of Crop Protection, Faculty of Agriculture, \\ University of Maiduguri, Maiduguri, Nigeria \\ ${ }^{2}$ Department of Crop Protection, Institute for Agricultural Research \\ Faculty of Agriculture, Ahmadu Bello University, Zaria, Nigeria \\ "E-mail address: algonialkali@yahoo.com
}

Keyword: RYMV Serological profiles; Hierarchical analysis; Northern Nigeria

\begin{abstract}
A panel of four monoclonal antibodies (MAbs) was used to study the immunological profile of Rice yellow mottle virus (RYMV) genus Sobemovirus. Serological profiles of 35 representative isolates of RYMV from Borno, Gombe, Kaduna, Kano, Niger, Sokoto and Zamfara states in Northern Nigeria. All the RYMV isolates were classified into three major serogroups (SG1, SG2 and SG3) and further separated into six subgroups (Sg1a, Sg1b, Sg2a, Sg2b, Sg3a and Sg3b). The results demonstrate a significant serological variability among RYMV isolates in Northern Nigeria. The hierarchical analysis of the serological profiles data revealed high viral load in Kano, Kaduna and Gombe states, these show they are suitable locations for strategic RYMV diagnostic and field epidemiological studies.
\end{abstract}

\section{INTRODUCTION}

Different serotypes (Sere, et al., 2007) and Pathotypes (Onasanya et al., 2004) of Rice yellow mottle virus (RYMV) genus Sobemovirus ( Fargette and Hull, 2005) isolates are known to exist. The virus is indigenous to the African continent (Abo, et al., 1998; Banwo, et al., 2004) and its neighbouring islands (Kouassi et al., 2005; Raymundo and Buddenhagen 1976). It was first discovered in Kenya in the 1960s (Bakker, 1974). The virus is now found in all sub-Saharan African countries and in Madagascar in the Indian Ocean (Raymundo and Buddenhagen, 1976; Abo, et al., 1998). It is characterized by high genetic variability due to its intrinsic high rates of mutation which is evident from the detection of several strains of the pathogen in some countries of Africa (Pinel et al., 2000; N'Guessan et al., 2001; Traore et al., 2005; Pinel-Galzi and Fargette, 2006). Five major serotypes have been identified, 3 in West and Central Africa (Ser1, Ser 2, Ser 3) and the other 2 in East Africa (Ser 4 and Ser 5) (Kanyeka et al. 2007). So far six strains of the virus have been reported, 3 in West and Central Africa (S1, S2 and S3) and 3 in East Africa (S4, S5 and S6) ( Pinel et al., 2000; Fargette and Konate, 2004; Kanyeka et al., 2007).

RYMV is transmitted through mechanical contact, sap inoculation, insect vectors, animals and culture practices ( Abo et al., 2002; Sarra and Peters, 2003; Sarra et al., 2004; Nwilene et al., 2009). Symptoms are quite variable and depend on the particular isolate-host combination but frequently include mottling, yellowing or orange leaf discolouration, reduced tillering, stunting of plants and sterility of flowers (Bakker, 1974; Fargette et al., 2002). Serious epidemics of RYMV have been reported in all rice ecological systems throughout Africa (Abo et al., 1998). Yield losses as high as $100 \%$ have often been reported, depending on the rice cultivars, time of infection, rice cropping systems and the isolates considered (Abo et al., 1998; Luzi-Kihupi et al., 2000). RYMV causes considerable damage in rice production. Early infection can lead to death of the plant in varieties which are highly susceptible (N'Guessan et al., 2001).

The diversity among RYMV isolates was reported immunologically with polyclonal and monoclonal antibodies (MAbs) (Fauquet and Thouvemel, 1977; Mansour and Baillis 1994; Konate 
et al., 1997; N'Guessan, et al., 2000; Alkali et al., 2012). Both serological and molecular analyses showed large virus diversity and geographical distribution of the strains, with a split between isolates from East and West Africa, and with different strains in the savanna and forested regions of West Africa (Traore et al., 2001). Both virulent and avirulent isolates were found among the strains, indicating that phytopathological traits of an isolate are not hereditary or confined to a specific strain or a particular region, but occurs naturally in different lineages in different parts of Africa (Sorha et al., 2005). Due to the coordinated efforts of African Scientists and their collaborators, representative isolates from most of the countries where RYMV causes economic losses have now been characterized (Abubakar et al., 2003). However, the significance of different isolates of RYMV in northern Nigeria has not extensively been studied. Thus, more study is needed for distinguishing and identifying serological profiles of RYMV, because of existence of different RYMV strains in the field. The study was carried out to determine the status and examine the variability of RYMV isolates found in the rice field in northern Nigeria

\section{MATERIALS AND METHODS}

\subsection{Field Survey and Sampling}

Surveys were carried out in rice fields during the wet and dry seasons in the year 2008 to 2010. Seven states (Borno, Gombe, Kaduna, Kano, Niger, Sokoto and Zamfara) were surveyed. Hotspots and epidemic areas within those states were surveyed. The surveys were carried out at the tillering and panicle initiation stages (Abo et al., 2002). In each field surveyed, three quadrants, $4 \times$ $4 \mathrm{~m}^{2}$ in size were randomly chosen (Alegbejo and Kashina, 2000). Infected rice leaves with and without RYMV- like symptoms were randomly sampled on the edges of the field, within the rice field and in the vicinity of the RYMV-infected rice plants using the visual diagnostic symptoms of RYMV (IRRI, 1996). Samples were collected using separate polyethylene bags, labeled, kept in ice box and transported to the Virology laboratory, Department Crop Protection, ABU, Zaria.

\subsection{RYMV Propagation}

The virus was recovered from the infected samples by back inoculation to the highly susceptible rice cultivars Bouake 189 (Onasanya et al., 2004). For inoculation tests, leaves from each specimen plant were pooled and then ground with a sterilized pestle and mortar, $1 \mathrm{~g}$ of the infected leaves in $10 \mathrm{ml}$ of $0.1 \mathrm{M}$ phosphate buffer (pH 7.4) (Luzi-Kihupi et al., 2000; (Sarra et al., 2004) ), containing carborundum powder (600 mesh) to act as an abrasive to facilitate virus entry into the plant. The extracts were used in inoculating 5 seedlings of Bouake 189 cultivar, planted in plastic pot filled with, sterilized soil to each isolate by mechanical (sap) inoculation. In order to avoid possible escapes from infection, all plants were re-inoculated twice at two day intervals as described by Thottappilly and Russell (1993). Uninoculated seedlings were included to serve as reference check. The test plants were kept for 3 weeks in the screenhouse and monitored for symptom(s) expression. Leaves of the test plants showing symptoms of RYMV were harvested and later used as sources of inocula during the serotyping and molecular characterization.

\subsection{Determination of Serological Profiles of RYMV}

Leaves of the test plant showing symptoms of RYMV inoculated from rice leaf samples were harvested and used for serological profile determination. The Triple Antibody Sandwich Enzyme Linked Immunosorbent Assay (TAS-ELISA) as outlined by Clark and Adams (1977) was used in the determination of serotypes of RYMV at the Virology laboratory, Department of Crop Protection, ABU, Zaria, Nigeria. Four monoclonal antibodies (AS-0478/11, AS-0478/12, AS0478/21 and AS- 0478/22) used were obtained from plant virus collection centre, DSMZ (German collections of Microorganism and cell cultures) Braunschweig, Germany. Polyclonal antibody was also used as non-discriminative with the same affinity to each RYMV isolate to detect virus independently of the serological properties of the isolates as a reference control. DAS-ELISA method as described by Clark and Adams (1977) was used. Colour change was measured with ELISA microreader (GF. M3000 Microplate reader, B.Bran Scientific \& Instrument Company, 
England). Negative- positive threshold were set at two times the mean of healthy control sample's absorbance values (A405 nm). Reaction was considered strong positive $(+++)$, mild $(++)$ or weak $(+)$ when absorbance value $\geq 4$ times, $3 \leq 4,3 \leq 2.5$ or $2 \leq 2.5$ of healthy control samples absorbance values, respectively. Hierarchical cluster dendrogram analysis was also generated from the data obtained with the four monoclonal antibodies reactivity from the TAS ELISA results. Using average linkage between isolates by rescaled distance cluster combine analysis (Graph pad instat statistical analysis package software).

\section{RESULTS}

\subsection{Serological Profile of RYMV Isolates}

Several variants of serological profiles were distinguished by their unusual reactions with four discriminating monoclonal antibodies (MAbs) panel (AS 0478/11, AS O478/12, AS0478/21 and AS 0478/22) raised against Nigerian isolates of RYMV. Twenty isolates from Kano, Kaduna and Gombe states showed strong positive reaction with all the MAbs and sixty five isolates from Gombe, Kano, Kaduna, Niger, Sokoto and Zamfara states showed mild to weak positive reactions with all the MAbs (Serotype A). Nine isolates from Borno and Gombe states showed mild reaction with MAbs 4 and weak reaction with MAbs 2 and MAbs 3. Similarly eight isolates from Kaduna and Kano states showed weak reaction with MAbs 2, MAbs 3 and MAbs 4 (serotype B). Five isolates from Gombe state showed mild positive reaction with MAbs 1, MAbs 2 and MAbs 3 (serotype C). Three isolates from Borno state showed weak to mild positive reactions with MAbs 3 and MAbs 4 while ten isolates from Sokoto and Zamfara states showed weak reactions with MAbs 3 and MAbs 4. (Serotype D). Four isolates from Borno and Sokoto states showed weak and mild positive reactions with MAbs 3, respectively (serotype E). Twelve isolates from Kano, Niger and Sokoto states showed weak positive reactions with MAbs 4 (serotype F).

\subsection{Hierarchical Cluster Dendrogram Analysis of RYMV Serological Profile}

There were considerable diverse serological relationships obtained among 35 representatives RYMV isolates serological profiles from seven states in northern Nigeria (Figure 1). The rescaled distance cluster combine, using average linkage between groups by hierarchical cluster dendrogram analysis, give rise to 0.25 to 1.00 coefficient similarity ranges. At 0.25 coefficient similarity levels, all the isolates were separated into three major serogroups (SG1, SG2 and SG3). While at 0.75 coefficient similarity levels SG1, SG2 and SG3 were further separated into two subgroups (Sg1a and $\mathrm{Sg} 1 \mathrm{~b})$, (Sg2a and $\mathrm{Sg} 2 \mathrm{~b})$ and (Sg3a and $\mathrm{Sg} 3 \mathrm{~b})$, respectively. Similarly, based on the rescaled distances among the isolates linkage analysed at 1.00 coefficient similarity levels, Some isolates were serologically identical at subgroups Sg1a (14), Sg1b (5), Sg2a (5), Sg2b (6), Sg3a (5) and $\mathrm{Sg} 3 \mathrm{~b}(5)$ respectively (Figure 1).

Table 1: Serological profile of RYMV isolates detected with monoclonal antibodies in Triple antibody sandwich enzyme linked immunosorbent assay (TAS ELISA)

\begin{tabular}{|c|c|c|c|c|c|c|c|}
\hline \multirow[t]{2}{*}{$\mathrm{S} / \mathrm{no}$} & \multirow[t]{2}{*}{ State } & \multirow[t]{2}{*}{ Site of collection } & \multirow{2}{*}{$\begin{array}{l}\text { Number of } \\
\text { isolates }\end{array}$} & \multicolumn{4}{|c|}{ Monoclonal antibodies } \\
\hline & & & & M1 & M2 & M3 & M4 \\
\hline 1 & Borno & Konduga 1 & 4 & - & + & + & ++ \\
\hline 2 & & Konduga 2 & 4 & - & - & + & - \\
\hline 3 & & Madurari & 3 & - & - & + & + \\
\hline 4 & & Malari & 2 & - & - & + & ++ \\
\hline 5 & Gombe & Dadinkowa1 & 5 & +++ & +++ & +++ & +++ \\
\hline 6 & & Dadinkowa 2 & 5 & ++ & ++ & ++ & - \\
\hline 7 & & Hinna 1 & 5 & ++ & +++ & +++ & + \\
\hline 8 & & Hinna 2 & 4 & - & ++ & ++ & + \\
\hline 9 & & Hinna 3 & 4 & +++ & +++ & +++ & + \\
\hline
\end{tabular}




\begin{tabular}{|c|c|c|c|c|c|c|c|}
\hline 10 & Kaduna & Bomo & 5 & - & + & + & ++ \\
\hline 11 & & Kurmi Bomo & 3 & +++ & +++ & +++ & +++ \\
\hline 12 & & Sayen Gobirawa & 5 & + & ++ & ++ & ++ \\
\hline 13 & & Nasarawan Buhari & 4 & + & + & ++ & + \\
\hline 14 & & Shika & 2 & ++ & ++ & ++ & ++ \\
\hline 15 & & Giwa & 2 & - & + & + & + \\
\hline 16 & & Anguwan Sogiji & 4 & +++ & +++ & +++ & +++ \\
\hline 17 & & Zabi & 2 & + & + & + & + \\
\hline 18 & & Hayen Sambo & 3 & + & + & ++ & + \\
\hline 19 & & Wusasa & 2 & + & + & ++ & + \\
\hline 20 & & Zango Shanu & 2 & - & + & + & + \\
\hline 21 & Kano & Kura & 5 & +++ & +++ & +++ & +++ \\
\hline 22 & & Chiromawa & 4 & ++ & ++ & +++ & +++ \\
\hline 23 & & Kadawa & 5 & + & + & ++ & +++ \\
\hline 24 & & Dakastalle & 4 & - & - & - & + \\
\hline 25 & & Kwanan Yari & 4 & - & + & + & + \\
\hline 26 & & Rano & 3 & +++ & +++ & +++ & +++ \\
\hline 27 & Niger & Wushishi & 4 & - & - & - & + \\
\hline 28 & & Badeggi & 5 & + & + & ++ & +++ \\
\hline 29 & Sokoto & Goronyo 1 & 5 & ++ & ++ & +++ & +++ \\
\hline 30 & & Goronyo 2 & 4 & - & - & + & + \\
\hline 31 & & Sokoto & 4 & - & - & - & + \\
\hline 32 & Zamfara & Talata Mafara 1 & 5 & - & - & + & + \\
\hline 33 & & Talata Mafara 2 & 4 & - & - & ++ & - \\
\hline 34 & & Rini & 5 & + & ++ & ++ & +++ \\
\hline 35 & & Birnin Tudu & 4 & - & - & + & + \\
\hline
\end{tabular}

Strong positive reaction $=+++$

Positive reaction $=++$

Weak positive reaction $=+$

Negative reaction $=$ - -
M1= Monoclonal antibody AS-0478/11

M2 = Monoclonal antibody AS-0478/12

M3 = Monoclonal antibody AS-0478/21

M4= Monoclonal antibody AS-0478/22 


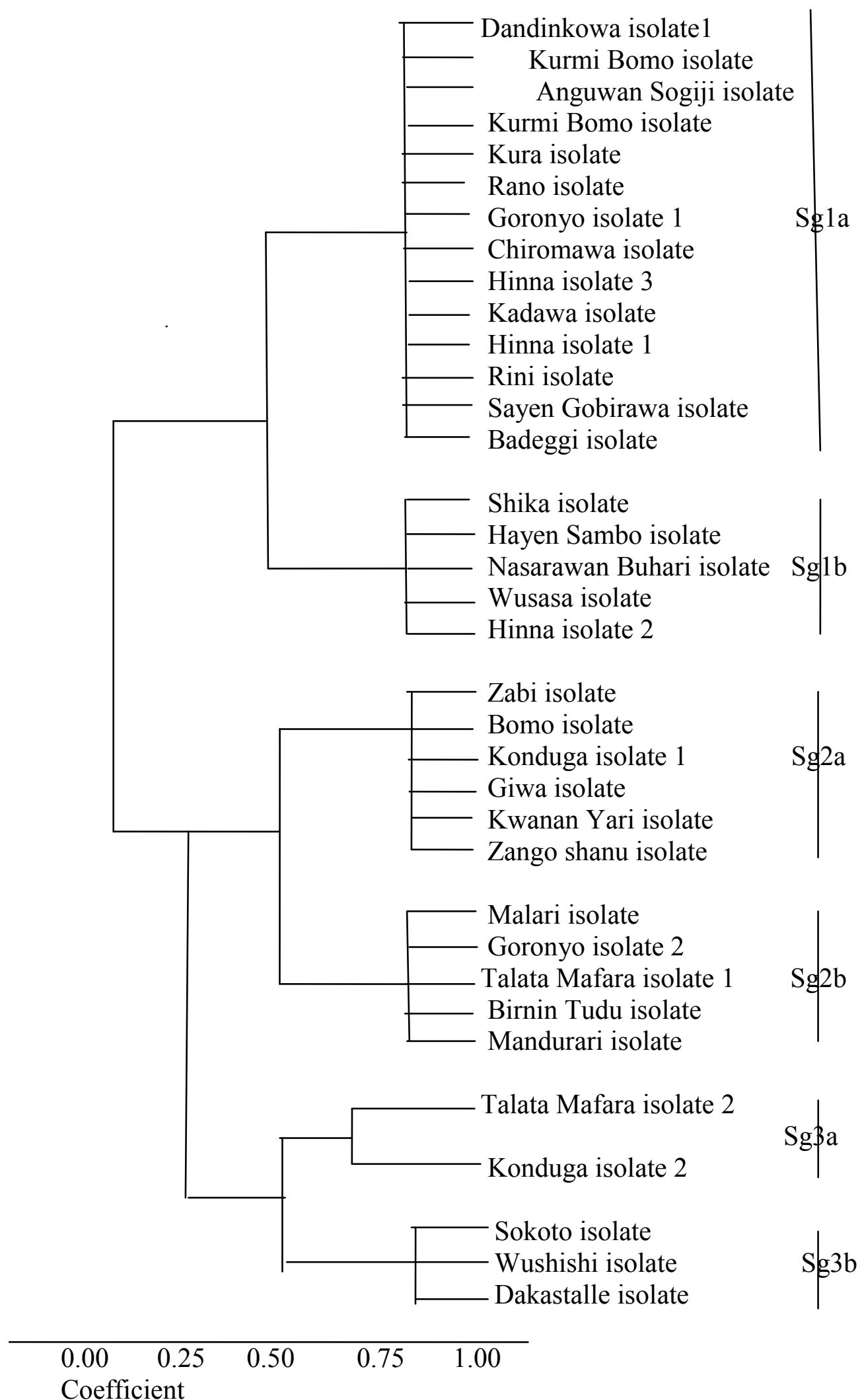

Fig. 1 Hierarchical relationship dendrogram of RYMV isolates of seven states in northern Nigeria derived from 35 serological profiles data using four monoclonal antibodies in TAS-ELISA

\section{DISCUSSION}

The occurrence of immunological diversity of the RYMV isolates assessed with panel of monoclonal antibodies in the surveyed areas, suggested that several serotypes co-exist in the surveyed ecological zones of northern guinea savanna (Kaduna state), southern guinea savanna (Niger state) and sudan savanna (Borno, Gombe, Kano, Sokoto and Zamfara states) in northern 
Nigeria. This result is consistent and complementary to the findings of N'Guessan et al. (2000) and Saluadeen et al. (2008) who reported that several serotypes of RYMV can co-exist in the same country. In addition to the serological relationship found in the surveyed areas, differential reactivity was observed among isolates collected from a few metres apart in the same area, but similar to an isolate from a different area. This explains the fact that within a set of isolates of related strains in the same host plant, many possibilities of interaction exist (Mathews, 1991). It also indicates the existence and levels of serodiversity among RYMV isolates in the surveyed areas. This is consistent with the earlier reports by Fargette et al. (1995) and N'Guessan et al. (1995) that isolates from the same areas could be quite different among each other and close to an isolate from a remote country. Sere et al. (2007) also reported that many isolates of RYMV emanating from same locality, field and host were observed to be serologically different. The serological similarities observed between isolates within the same and different localities in the surveyed areas, confirm the great cross-infection potential of RYMV transmitted under natural conditions by different insect vectors (Bakker, 1971; Hammond et al., 1999). This possibly accounted for the different serological profiles obtained among different RYMV isolates collected in the surveyed areas. RYMV has been described as a variable virus with many pathological and serological variants (Konate et al., 1997; Sasaya et al., 1997; NGuessan et al., 2000 and Sere et al., 2007; Onasanya et al., 2011). This result are in agreement with the observed prevalence of several variants of the serological profiles recorded in this study, distinguished by their unusual reactions with the same MAbs tested in some isolates collected across the surveyed areas. This information implies that weak and strong reaction recorded in this study by some of the isolates tested with the panel of MAbs, can probably be ascribed to weak reaction with the virus isolates rather than low concentration of the virus in the infected tissue, because a conspicuous symptom was observed after propagating the virus in susceptible rice cultivar BOUAKE 189 (to most of the isolates used.). Similar results were reported by Mansour and Baillis (1994) who used RYMV isolates collected from rice in Cote d'lvoire, Kenya, Niger, Nigeria and Sierra Leone.

Based on the reaction pattern to the panel of MAbs in TAS- ELISA six serological profiles or groups have been identified (Sep A to F) in this study. The Sep A isolates were present in Gombe, Kaduna, Kano, Niger, Sokoto and Zamfara states. Sep B isolates were common in Borno, Gombe, Kaduna and Kano states. Sep C isolate was identified only in Gombe state. Sep D isolate were detected in Borno, Sokoto and Zamfara states, while Sep E isolates were identified in Borno and Zamfara states. Sep F isolates were identified in Kano, Niger and Sokoto states. However, serological typing sometimes gives ambiguous result and could be less discriminating than molecular typing (Kanyeka et al., 2007). This may probably explain the fact that some of the isolates grouped under the same serological profiles had no reaction with the same specific primer, but had similar reaction with other isolates grouped under different serological profiles in molecular typing in this study. It could also explain the fact that within a set of isolates of related strains in the same host plant, many possibilities of interaction exist (Mathews, 1991). Hierarchical classification of all the RYMV isolates into three main serogroups (SG1, SG2 and SG3) and six subgroups (Sg1a, $\mathrm{Sg} 1 \mathrm{~b}, \mathrm{Sg} 2 \mathrm{a}, \mathrm{Sg} 2 \mathrm{~b}, \mathrm{Sg} 3 \mathrm{a}$ and $\mathrm{Sg} 3 \mathrm{~b}$ ) in this study indicates the existence and levels of serodiversity among RYMV isolates in northern Nigeria. Such possibilities of interaction within a set of isolates of related strains might lead to frequent occurrence of mutants which might be responsible for the high level of serological variation among the isolates (Boccard and Baulcombe, 1993). Similarly Sere et al. (2005) suggested that as a result of possible interaction between different strains of the same isolate in the same host plant, which varies from one ecological zone to another, diverse serological variability tends to exist between isolates of RYMV in West Africa. High serological profile or serotype diversity of RYMV found in this study may be associated with occurrence of resistance breaking isolates (Traore et al., 2006), which urgently calls for deliberate effort to study the potential problem for future development of resistant cultivar to RYMV in the surveyed areas. Similarly hierarchical classification of RYMV isolates into three main serogroup and six subgroup obtained from cross reactivity of four monoclonal antibodies derived from serological profiles data in TAS-ELISA, could be useful for epidemiological studies to assess isolate identity and interaction 
in the fields. The high viral load in some of the surveyed sites in Gombe, Kano, Kaduna, Niger and Zamfara states, implies that these are suitable locations for strategic studies aimed at designing management interventions against RYMV disease.

\section{CONCLUSION}

A panel of four monoclonal antibodies (MAbs) was used to study the immunological profile of Rice yellow mottle virus (RYMV) genus Sobemovirus. Serological profiles of 35 representative isolates of RYMV from Borno, Gombe, Kaduna, Kano, Niger, Sokoto and Zamfara states in Northern Nigeria. All the RYMV isolates were classified into three major serogroups (SG1, SG2 and SG3) and further separated into six subgroups (Sg1a, Sg1b, Sg2a, Sg2b, Sg3a and Sg3b). The results demonstrate a significant serological variability among RYMV isolates in Northern Nigeria.

\section{References}

[1] Abo, M.E., Sy, A. A. and Alegbejo, M. D. (1998). Rice yellow mottle virus (RYMV) in Africa. Evolution, distribution and economic significance on sustainable rice production and management strategies. Journal of Sustainable Agriculture. 11 (2/3): 85-111.

[2] Abo, M. E., Ukwungwu M.N. and Onasanya, A. ( 2002). The distribution, incidence, natural reservoir hosts and insect vectors of Rice yellow mottle virus (RYMV), genus Sobemovirus in Northern Nigeria. Tropiculture, 20: 198-202.

[3] Abubakar, Z., Ali, F., Pinel, A., Traore, O., N'Guessan, P., Notteghem, J.-L., Kimmins, F., Konate, G. and Fargette, D. (2003). Phylogeography of Rice yellow mottle virus in Africa. Journal of General Virology, 84: 733-743.

[4] Alegbejo, M. D. and Kashina, B.D. (2000). Survey of weed hosts of blackeye cowpea mosaic and cowpea aphid-borne mosaic potyviruses at Samaru, Nigeria. Journal of Pure and Applied Science, 3(2): 119- 125.

[5] Alkali, G., Alegbejo, M. D., Kashina, B. D. and Banwo, O.O. (2012) .Diversity of serological profiles of Rice yellow mottle virus isolates in Northern Nigeria. Biological and Environmental sciences Journal for the Tropics 9((3): 168- 173.

[6] Bakker, W. (1971). Three new beetles vectors of rice yellow mottle virus in Kenya. Netherlands Journal of plant pathology, 77: 201-206.

[7] Bakker, W. (1974). Characterization and ecological aspect of rice yellow mottle virus in Kenya. Agricultural Research Doctoral thesis, University of WASeningen, the Netherlands, $152 \mathrm{p}$.

[8] Banwo, O. O., Winter, S., Koerbler, M., Abdallah, N. and Makundi, R. H. (2004b). Molecular variability and distribution of Rice yellow mottle virus in Tanzania. Acta Virologica, 48: 67-71.

[9] Boccard, F. and Baulcombe, D. (1993). Mutational analysis of Cis-acting sequence and gene function in RNA 3 of cucumber mosaic mosaic virus. Virology, 198: 563-578 .

[10] Clark, M. K. and Adams, A.N. (1977). Characteristics of the micro plate method of enzyme linked immunosorbent assay for the detection of plants viruses. Journal of General Virology, 34: 475-483.

[11] Fargette, D., Pinel, A., Albar, L., Sadiky, R., Nguessan, P., Frutos, R.., Nottengham, J. L. and Ghesquine, A. (1995). Assessment of biological, serological and molecular variability of a range of RYMV isolates from different geographical areas. Paper presented at the $1^{\text {st }}$ International Symposium on RYMV, 18-22 september, 1995 Mbe,WARDA/ADRAO, Bouake, Cote d"Ivoire. 
[12] Fargette, D., Pinel, A., Halimi, H., Brugidau, C., Fauquent, C., and Van-Regenmortel, M. (2002). Comparing of molecular and immunological typing of isolates or rice yellow mottle virus. Archieves of Virology 147: 583-596.

[13] Fargette, D. and Konaté, G. (2004). An overview of Rice yellow mottle virus. In: proceeding of a Conference organized by IITA; Plant Virology for Sub-Saharan Africa 4-8 June 2001, Ibadan, Nigeria. 1-17.

[14] Fauquet, C. M. and Thouvenel, J. C. (1977). Isolation of Rice yellow mottle virus in Cote d'Ivoire. Plant Disease Reporter, 61: 443-446.

[15] Hammond, J., Lecoq, H. and Reccah, B. (1999). Epidemiologcal risk from mixed virus infections and transgenic plant expressing viral genes. Advances in virus Research, 54: 189314.

[16] Hull, R. and Fargette, D. (2005). Sobemovirus In: Fauquet, C.M., Mayo,M. A., Maniloff, J., Desselberger, U., Ball, L.A. (eds) Virus Taxonomy; Classification and Nomenclature of Viruses. Eighth Report of the International Committee on Taxonomy of Viruses pp. 885-890 Elsevier/Academic Press, London,UK

[17] IRRI (1996). INGER. Genetic Resources Centre Standard Evaluation system for Rice, IRRI, Los Banus the Philippines $4^{\text {th }}$ edition pp. 25.

[18] Kanyeka, Z. L., Sanya, E., Fargette, D., Pinel-Galzi, A. and Herbrard, E. (2007). Distribution and diversity of local strains of rice yellow mttle virus in Tanzania. African Crop Science Journal, 15(4) :201-209.

[19] Konate, G.O., Traore, O. and Coulibaly, M. (1997). Characterization of rice yellow mottle virus isolates in Sudano-Sahelian area. Archives of Virology, 142:1117-1124.

[20] Kouassi, N. K., N'Guessan, P., Albar, L., Fauquet, C., Brugidou, C. (2005). Distribution and characterization of Rice yellow mottle virus: a threat to African farmers. Plant Disease, 89:124-132.

[21] Luzi-Kihupi, A. Mcozi, M.R.S., Mahagala, R.B., Mushobozy, D.M.K. and Nchimbi-msolla, S. (2000). Occurrence of rice yellow mottle virus in Tanzania. Tanzania Journal of Agricultural Science, 3 (2): 87-96.

[22] Mansour, A. N. and Baillis, K. W. (1994). Serological relationship among rice yellow mottle virus isolates. Annals of Applied Biology, 125: 133-140.

[23] Matthews, R.E.F. (1991). Plant Virology. Academic Press, London, UK. 835 PP.

[24] N'Guessan, N. P. Sy. A. A. and Fargette, D. (1995).Charaterization Biologique at Seroqiqus d' isolats du virus de la morbrare du riz en. Cote d'Ivoire. Paper presented at the $1^{\text {st }}$ International Symposium on RYMV, 18-22 september, 1995 Mbe,WARDA/ADRAO, Bouake, Cote d'Ivoire.

[25] N'Guessan, P., Pinel, A., Caruana, M., Frutos, R., Sy, A., Ghesquiere, A., and Fargette, D. (2000). Evidence of the presence of two serotypes of Rice yellow mottle sobemovirus in Côte d'Ivoire. European Journal of Plant Pathology. 106:167- 178.

[26] N'Guessan, P. N., Pinel, A., Sy., A. A., Ghesquire, A. and Fargette, D. (2001). Distribution, pathogenicity and interactions of two strains of Rice yellow mottle virus in forested and savanna zones of West Africa. Plant Disease, 85(1): 59-64.

[27] Nwilene, F. E., Sere, Y., Ndjonodjop, M. N., Abo, M. E., Traore, A. K., Asidi, A. N., Onasanya, A., Togola, A. and Agunbade, T. A. (2009). Rice yellow mottle virus (RYMV) and its insects vectors: ecology and control- field guide and technical manual. WARDA, Cotonou, $36 \mathrm{pp}$. 
[28] Onasanya, A., Sere Y., Nwilene, F., Abo, M. E. and Akator, K. (2004). Reactions and resistance status of differential rice genotypes to rice yellow mottle virus Genus Sobemovirus in Cote d'Ivoire. Asian Journal of plant science, 3 (6):718-723.

[29] Onasanya, R. O., Olafolaji, D. B., Onasanya, A., Sere, Y., Nwilene, F. E., Wopereis, M. and Kiepe, P. (2011). Occurrence, distribution and characterazation of Rice yellow mottle virus genus Sobemovirus in Southwest, Nigeria. Trends in Applied Sciences Research, 6: 13011323.

[30] Pinel, A., N'Guerssan,. P., Bousalem, M. and Fargette, D. (2000). Molecular variability of geographical distinct isolates of rice yellow mottle virus in Africa. Archieves of Virology 145:1621-1638.

[31] Pinel-Galzi, A. and Fargette, D. (2006). First report of rice yellow mottle virus in rice in Uganda. Plant Disease, 90: 683.

[32] Raymundo, S. A. and Buddenhagen, I. W. (1976). A rice disease in West Africa International Rice Commission Newslette, $r$ 29:51-53.

[33] Salaudeen, M.T., Banwo, O. O., Kashina, B. D. and Alegbejo, M. D. (2008). Effect of Rice yellow mottle Sobemovirus on yield in some rice cultivars. Biological and Environmental Sciences Journal for the Tropics, 5(1):27-34.

[34] Sarra, S. and Peters, D. (2003). Rice yellow mottle virus is transmitted by Cows, Donkeys, and Grass cuts in irrigated rice crops. Plant Disease, 87: 804 -808.

[35] Sarra, S., Oevering, P., Guinda, S. and Peters, D. (2004). Wind-mediated spread of rice yellow mottle virus RYMV in irrigated rice crops. Plant Pathology, 53:143-148.

[36] Sasaya, T., Shimizu, T., Nazu, Y., Nishiguichi, M., Inouuya, N. and Kuganazawa, H. (1997). Biological, serological and molecular variabilities of Clover yellow vein virus. Phytopathology, 133: 255-263.

[37] Séré, Y., Onasanya, A., Afolabi, A. S. and Abo, M. E. (2005). Evaluation and potential of double immunodifusion gel essay for serological characterization of Rice yellow mottle virus isolates in West Africa. African Journal of Biotechnology, 4 (2): 197-205.

[38] Séré, Y., Onasanya, A., Akator, K., Afolabi, A. S. and Abo, M. E. (2007). Serological differentiation indices and phylogenetic analysis of Rice yellow mottle virus isolates in Cote d'Ivoire. Journal of Biological Sciences, 7(7): 1147-1154.

[39] Sorho, F., Pinel, A., Traoré, O., Bersoult, A., Ghesquière, A., Hébrard, E., Konaté, G., Séré, Y. and Fargette, D. (2005). Durability of natural and transgenic resistances in rice to Rice yellow mottle virus. European Journal of Plant Pathology, 112: 349-359.

[40] Thottappilly, G. and Rossel, H.W. (1993). Plant virus disease of importance to African Agriculture. Journal of Phytopathology, 134: 205-288.

[41] Traore, O., Pinel, A., Fargette, D. and Konate, G. (2001). First report and characterization of Rice yellow mottle virus in Central Africa. Plant Disease, 85:920.

[42] Traore, O., Sorho, F., Pinel, A., Abubakar, Z., Banwo, O.O., Maley, J., Herbrard, E., Winter, S., Sere, C., Konate, G. and Fargette, D. (2005). Processes of diversification and dispersion of Rice yellow mottle virus inferred from large scale and high resolution phylogeographical studies. Molecular Ecology, 14:2097-2110.

[43] Traoré, O., Pine, A., Hébrard, E., Dieudonné Gumedzoé, M. Y., Fargette, D., Traoré S. A., and Konaté, G., (2006). Occurrence of Resistance-Breaking Isolates of Rice yellow mottle virus in West and Central Africa. Plant Disease, 90:259-263. 